\title{
DISTRIBUTION OF SOLUBLE AND INSOLUBLE CHEMICAL SPECIES OF CHROMIUM (III) AND (VI) IN AQUEOUS SOLUTIONS
}

\author{
Oxana Spinu \\ Institute of Chemistry of Academy of Sciences of Moldova, 3, Academiei str., Chisinau, MD 2028, Republic of Moldova \\ e-mail: oxana_spinu@yahoo.com; phone (+373 22) 739781
}

\begin{abstract}
On the basis of currently revised thermodynamic data for $\mathrm{Cr}(\mathrm{III})$ and $\mathrm{Cr}(\mathrm{VI})$ hydrolysis and photolytic equilibria in addition to original thermodynamic and graphical approach, used in this paper, the repartition of their soluble and insoluble chemical species has been investigated. By means of the diagrams " $\Delta \mathrm{G}-\mathrm{pH}$ ", the areas of thermodynamic stability of chromium(III) hydroxide have been established for a number of the analytical concentration of $\mathrm{Cr}(\mathrm{III})$ in heterogeneous mixtures. The degree of polynuclearity for $\mathrm{Cr}$ (III) and $\mathrm{Cr}(\mathrm{VI})$ has been calculated for different initial composition of aqueous solutions. The diagrams of heterogeneous and homogeneous chemical equilibria have been used for graphical representation of complex equilibria in aqueous solutions containing $\mathrm{Cr}(\mathrm{III})$ and $\mathrm{Cr}(\mathrm{VI})$. The obtained calculated results correlate well with existing experimental data.
\end{abstract}

Keywords: chemical equilibrium, chromium complexes, distribution diagram, Gibbs energy.

\section{Introduction}

The increased knowledge regarding the behavior of chromium in natural waters and soils is essential for the complete and accurate determination of its possible toxicity to the particular ecosystem, as well as for the development of methods which minimize the risk of pollution areas. Due to the complex, heterogeneous nature of the soil and surface waters, the determination of the chromium behavior may be a very difficult task. Only by understanding the specific mechanism of the reactions, in which chrome may participate, one can expect a truthful forecast of its behavior.

Chromium $(\mathrm{Cr})$ is one of the most strategically important materials in the world, having a wide range of applications in metallurgy and chemical industry. Alloys containing chromium metal enhance such properties as the resistance, stability to corrosion and oxidation. Furthermore, chromium is used as an additive in the production of stainless steel, in the treatment of leather, metal plating, in the production of catalysts and in other industries [1].

Chromium is rarely found in nature as a free metal. Chromium can exist in all degrees of oxidation from 0 to VI. The most typical chromium degrees of oxidation are $+2,+3$ and +6 , but +3 and +6 are most stable ones, while the oxidation states $+1,+4$ and +5 are rare found in nature. $\mathrm{Cr}(\mathrm{IIII})$ is much less toxic than $\mathrm{Cr}(\mathrm{VI})$ [3]. $\mathrm{Cr}(\mathrm{III})$ is the most stable form in the environment and biological systems. It is an essential trace element in the human body and participates, in combination with various enzymes, in the metabolism of sugars, proteins and fats. The recommended daily dose for an adult is between 0.5 to $1.0 \mathrm{mg} / \mathrm{day}$ [4].

According to the World Health Organization (WHO) and the International Agency for Research on Cancer $\mathrm{Cr}(\mathrm{VI})$ is a carcinogen form. The inhalation of $\mathrm{Cr}(\mathrm{VI})$ can cause irritation of the nose and nosebleeds. After the contact of $\mathrm{Cr}(\mathrm{VI})$ with the human body, skin rashes, indigestion and ulcers, respiratory diseases, weakness of immune system, kidney and liver damage, alteration of genetic material, lung cancer and death may appear or be caused [5]. The WHO considers $\mathrm{Cr}(\mathrm{VI})$ as a pollutant of main concern. The concentration of $0.05 \mathrm{mg} / \mathrm{L}$ for $\mathrm{Cr}(\mathrm{VI})$ has been adopted as the maximum allowable concentration (MAC) for drinking water. That is why a constant monitoring and analysis of chromium in the environment is becoming a requirement. The natural sources of chromium in natural waters are such processes as erosion of rocks and run-off from the land-based systems. The chromium concentration in rivers and lakes is generally limited to $0.5-100.0 \mu \mathrm{g} / \mathrm{L}$ [6], while in marine waters it ranges between $0.156-0.260 \mu \mathrm{g} / \mathrm{L}$ [7] .

The concentration of chromium in contaminated area may be much higher. The local increase in the concentration of chromium in waters (mainly in rivers) is due to wastewater discharges from the metallurgy, electroplating, chemical and leather industries, as well as the health leach dumps etc. The concentration and type of substances present in the effluent depend on the nature of industrial processes using chromium [8].

In natural waters, chromium exists in only two stable states, $\mathrm{Cr}(\mathrm{III})$ and $\mathrm{Cr}(\mathrm{VI})$. The presence and the ratio between these two forms dependent on the various processes that include chemical, photochemical, and redox processes, reactions of precipitation/dissolution and adsorption/desorption. The high concentrations of chromium in the nature cause mutagenic, teratogenic or carcinogenic effects.

The highest concentration of chromium in the Chisinau city was found in samples of snails collected in the industrial zone, indicating a strong pollution of nearby territory by this metal (snails were collected in the vicinity of the factory of leather processing "Piele SA") and near the gas station [9]. A relatively high concentration of chromium was detected in immature specimens of Helix Lutescens $(2.0 \mu \mathrm{g} / \mathrm{g})$. The Cr concentration in the soil in the industrial area was particularly high $-1079.7 \mu \mathrm{g} / \mathrm{g}$. 
The aim of this paper is the thermodynamic analysis, based on the selected recent experimental data, and graphical representation of the distribution of various soluble and insoluble chemical forms of chromium (III) and (VI) for different concentrations in a wide range of $\mathrm{pH}$ values.

\section{Theoretical part}

Thermodynamic calculations and graphic representation of the distribution of chemical forms of Cr(III) and Cr(VI)

In this paper the diagrams of heterogeneous chemical equilibria (DHCE) have been used for graphical representation of complex equilibria in aqueous solutions containing $\mathrm{Cr}$ (III) [10]. Their construction is based on the determination of the thermodynamic stability areas of the solid phase [11-13], derived by the method of residual concentrations (RC) $[14,15]$. The biphasic systems consisting of the soil solution and minerals, in which a number of chemical reactions occur simultaneously, are heterogeneous systems. These diagrams are similar in appearance to the distribution diagram in the case of homogeneous (single-phase) systems [16], however, the principle of their construction differs significantly from the past ones. phase):

Besides the process of chromium hydroxide $\mathrm{Cr}(\mathrm{OH})_{3(\mathrm{~S})}$ dissolution (the subscript symbol " $\mathrm{S}$ " denotes solid

$\mathrm{Cr}(\mathrm{OH})_{3(\mathrm{~S})}+3 \mathrm{H}^{+} \leftrightarrow \mathrm{Cr}^{3+}+3 \mathrm{H}_{2} \mathrm{O}, \quad \log \mathrm{K}_{\mathrm{S}}=\log \left(\left[\mathrm{Cr}^{3+}\right]\left[\mathrm{H}^{+}\right]^{-3}\right)=9.35$

the hydrolysis reaction with the formation of mono- and polynuclear hydroxocomplexes $\mathrm{Cr}_{i}(\mathrm{OH})_{j}^{3 i-j}$ are taken into account [17]:

$i \mathrm{Cr}^{3+}+j \mathrm{H}_{2} \mathrm{O} \leftrightarrow \mathrm{Cr}_{\mathrm{i}}(\mathrm{OH})_{\mathrm{j}}^{3 \mathrm{i}-\mathrm{j}}+j \mathrm{H}^{+}, \quad K_{i j}$

Near to the equations of reactions their corresponding equilibrium constants $K_{s}$ and $K_{i j}$ are written. $[14,15]$

The conditions of mass balance (MB) in this system are formulated on the basis of residual concentrations, RC

$$
\begin{aligned}
& C_{C r}^{0}=C_{C r}^{r}+\Delta C_{C r}=\sum_{i=1} \sum_{j=0} i\left[C r_{i}(\mathrm{OH})_{j}\right]+\Delta C_{C r} \\
& C_{H}^{0}=C_{H}^{r}+\Delta C_{H}=[H]-[O H]-\sum_{i=1} \sum_{j=1} j\left[C_{i}(O H)_{j}\right]+\Delta C_{H}
\end{aligned}
$$

For convenience, the notation of species charges is omitted. The quantities $C^{0}{ }_{i}$ and $C^{r}{ }_{i}$ in Eq.(3) and Eq.(4) represent, respectively, the analytical (total) and residual concentrations of the " $i$ " component in the heterogeneous system under consideration. In Eq.(3) and Eq.(4) by $\Delta C_{i}$ the amount of solid phase in one liter of solution is denoted. In Eq.(4), $C_{H}^{0}$ symbolizes the excess of the $\mathrm{H}^{+}$ions towards the hydroxyl ions in the two-phase mixture, $C^{0}{ }_{H}=-C^{0}{ }_{O H}$. From the stoichiometric composition of chromium hydroxide $\mathrm{Cr}(\mathrm{OH})_{3(\mathrm{~S})}$, the following relation is derived:

$1 / 3 \Delta C_{O H}=\Delta C_{C r}$

Moreover, in the framework of the RC method, it can be written: $\Delta C_{O H}=-\Delta C_{H}$ and $C_{O H}^{r}=-C_{H}^{r}$. The equilibrium concentration of chromium ion $\left[\mathrm{Cr}^{3+}\right]$ is determined from the equilibrium constant $K_{S}$ (Eq.(1)). In view of the law of mass action (LMA) and relation (5), from the mass balance (3) and (4) at a given $\mathrm{pH}$, we obtain an equation with one unknown - $\Delta C_{C r}$, which can be easily solved by the known numerical methods. From the combined aforementioned equations of LMA and MB, one can calculate the distribution diagram of the chromium ion in the solid phase and complex species in the liquid phase (aqueous solution), i.e. the DHCE. The following equations for calculating the partial molar fraction of species $f_{i}$ in the heterogeneous system, wherein the reactions (1) and (2) proceed simultaneously, have been used:

$f_{S}=\frac{{ }^{\Delta C}{ }_{C r}}{C_{C r}^{0}}, \quad f_{\text {tot }}=\frac{C_{C r}^{r}}{C_{C r}^{0}}, \quad f_{C r}=\frac{[C r]}{C_{C r}^{0}}, \quad f_{i j}=\frac{i\left[C_{i}(\mathrm{OH})_{j}\right]}{C_{C r}^{0}}$

Here the subscript "tot" means the sum of the molar fractions of all the soluble species. On the basis of Eq.(3), Eq.(5) and Eq.(6) the validity of the following equation can be verified:

$$
f_{S}+f_{\text {tot }}=f_{S}+f_{C r}+\sum_{i=1} \sum_{j=1} f_{i j}
$$

When $i>1$ for the hydroxo-complexes of type $\mathrm{Cr}_{i}(\mathrm{OH})_{j}$, the polynuclear complexes are formed. In order to appreciate their amount, the degree of the polynuclear hydroxo-complex formation has been calculated [18]:

$P=\sum_{i=1} \sum_{j=0} i f_{i j}$ 
If $P>1$, then the polynuclear hydroxo-complexes are present in the solution.

In appearance DHCE are similar to the diagrams of distribution of the species in homogeneous solution. The latter are usually built in the coordinates $f_{i}(\mathrm{pH})$, as in the absence of polynuclear complexes, the molar fractions of species $f_{i}$ in aqueous solution are a function of the solution $\mathrm{pH}$ and do not depend on the initial concentrations of components. In the case of heterogeneous equilibria, the molar fractions of species depend also on the initial composition of the mixture, being at a given $\mathrm{pH}$ a function of one variable $f_{i}=f\left(\mathrm{C}^{0}(\mathrm{Cr})\right)$. In this case, it is desirable to build the diagrams in the coordinates $\left(f_{i}, \mathrm{pH}\right)$, fixing the values of other variables. The procedure for constructing DHCE includes the following successive steps:

1) Thermodynamic calculation of the $\mathrm{Cr}(\mathrm{OH})_{3(S)}$ stability area. The authors [9-13] derived the equation for calculating the Gibbs energy of complex process $\Delta G_{S, t o t}$, in which reactions (1) and (2) occur simultaneously:

$\Delta G_{S, t o t}=-R T \ln \frac{C_{C r}^{r}}{C_{C r}^{0}}$

The solid phase $\operatorname{Cr}(\mathrm{OH})_{3(S)}$ is stable if $\Delta G_{S, t o t}>0$. The condition $\Delta G_{S, t o t}=0$ corresponds to the beginning of its dissolution (or precipitation).

2) Subsequently, the molar fractions $f_{i}$ of all the chemical species containing chromium ion are calculated by the Eq.(6) within the stability area of $\mathrm{Cr}(\mathrm{OH})_{3(S)}$ defined in the previous stage.

3) For completeness, outside this area, i.e. for homogeneous aqueous solutions, the molar fractions are calculated by the usual equations for the distribution diagrams [16]. In this case, the $f$ value does not depend on the initial concentrations of examined components under the conditions of formation of only mononuclear complex species.

Distribution diagrams of chemical forms Cr(VI) are calculated by the usual equations for the distribution in the homogeneous systems. The chemical equilibria and their equilibrium constants, used in this paper, are given in Table 1.

Equilibrium constants used for calculations in this work.

\begin{tabular}{|c|c|c|}
\hline Chemical reactions & $\log K$ & Source \\
\hline $\mathrm{Cr}^{3+}+\mathrm{H}_{2} \mathrm{O}=\mathrm{CrOH}^{2+}+\mathrm{H}^{+}$ & -3.57 & {$[17]$} \\
\hline $\mathrm{Cr}^{3+}+2 \mathrm{H}_{2} \mathrm{O}=\mathrm{Cr}(\mathrm{OH})_{2}^{+}+2 \mathrm{H}^{+}$ & -9.84 & [17] \\
\hline $\mathrm{Cr}^{3+}+3 \mathrm{H}_{2} \mathrm{O}=\mathrm{Cr}(\mathrm{OH})_{3(\mathrm{aq})}^{0}+3 \mathrm{H}^{+}$ & -16.19 & [17] \\
\hline $\mathrm{Cr}^{3+}+4 \mathrm{H}_{2} \mathrm{O}=\mathrm{Cr}(\mathrm{OH})_{4}^{-}+4 \mathrm{H}^{+}$ & -27.65 & [17] \\
\hline $2 \mathrm{Cr}^{3+}+2 \mathrm{H}_{2} \mathrm{O}=\mathrm{Cr}_{2}(\mathrm{OH})_{2}^{4+}+2 \mathrm{H}^{+}$ & -5.00 & [19] \\
\hline $3 \mathrm{Cr}^{3+}+4 \mathrm{H}_{2} \mathrm{O}=\mathrm{Cr}_{3}(\mathrm{OH})_{4}^{5+}+4 \mathrm{H}^{+}$ & -10.75 & [19] \\
\hline $4 \mathrm{Cr}^{3+}+6 \mathrm{H}_{2} \mathrm{O}=\mathrm{Cr}_{4}(\mathrm{OH}) \frac{6+}{6}+6 \mathrm{H}^{+}$ & -13.86 & [20] \\
\hline $\mathrm{Cr}(\mathrm{OH})_{3(\mathrm{~S})}+3 \mathrm{H}^{+}=\mathrm{Cr}^{3+}+3 \mathrm{H}_{2} \mathrm{O}$ & 9.35 & [19] \\
\hline $\mathrm{CrO}_{4}^{2-}+\mathrm{H}^{+}==\mathrm{HCrO}_{4}^{-}$ & 6.55 & [19] \\
\hline $\mathrm{CrO}_{4}^{2-}+2 \mathrm{H}^{+}==\mathrm{H}_{2} \mathrm{CrO}_{4}$ & 6.31 & [19] \\
\hline $2 \mathrm{CrO}_{4}^{2-}+2 \mathrm{H}^{+}==\mathrm{Cr}_{2} \mathrm{O}_{7}^{2-}+\mathrm{H}_{2} \mathrm{O}$ & 14.7 & [19] \\
\hline
\end{tabular}




\section{Results and discussion}

The data regarding the thermodynamic stability of the chromium (III) hydroxide, calculated by Eq.(9), are depicted graphically on the Figure 1. As one can see, the area of predominance of the solid phase diminishes noticeably with decreasing the analytical concentration of $\mathrm{Cr}(\mathrm{III})$ in the heterogeneous mixture.

According to the thermodynamic calculations in this paper, depending on the total (analytical) concentration of chromium and acidity of solutions, $\mathrm{Cr}$ (III) can exist in aqueous solution as hydroxo complexes, $\mathrm{such}$ as $\mathrm{Cr}(\mathrm{OH})^{2+}$, $\mathrm{Cr}(\mathrm{OH})_{2}{ }^{+}, \mathrm{Cr}(\mathrm{OH})_{3}, \mathrm{Cr}(\mathrm{OH})_{4}{ }^{-}, \mathrm{Cr}_{2}(\mathrm{OH})_{2}{ }^{4+}$ and $\mathrm{Cr}_{3}(\mathrm{OH})_{4}{ }^{5+}$. Figure 2 shows DHCE for $\mathrm{C}^{0}(\mathrm{Cr})=10^{-6} \mathrm{M}$. Hence one can conclude that $\mathrm{Cr}^{3+}$ exists only in highly acidic environments, $\mathrm{Cr}(\mathrm{OH})^{2+}$ predominates at the $\mathrm{pH}$ values of 3.7 - 6.0, while the solid phase $\mathrm{Cr}(\mathrm{OH})_{3(\mathrm{~S})}$ is prevailing at $\mathrm{pH}>6.0$. In highly alkaline solutions, at $\mathrm{pH}>12$, chromium in the solution is in the anionic form of hydroxocomplex $\mathrm{Cr}(\mathrm{OH})_{4}^{-}$.

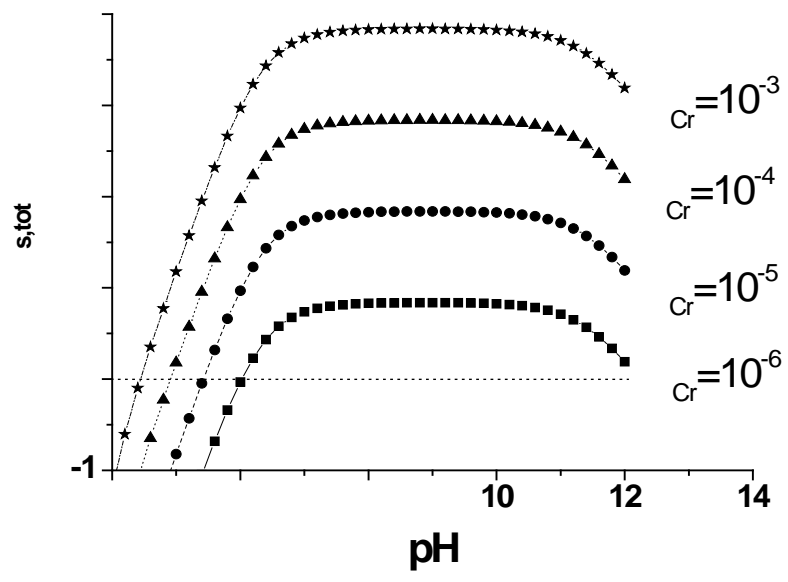

Figure 1. The total Gibbs energy versus pH for the system "saturated aqueous solution - Cr(III) hydroxide" for different analytical concentrations of $\mathrm{Cr}$ (III).

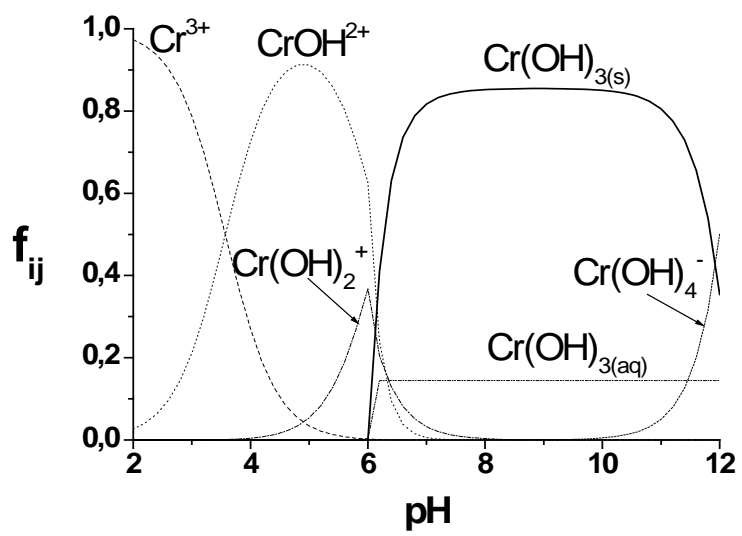

Figure 2. The curves of distribution of the $\mathrm{Cr}$ (III) hydroxocomplexes as a function of $\mathrm{pH}$ for $\mathrm{C}^{0}(\mathrm{Cr})=10^{-6} \mathrm{M}$.

By increasing the analytical concentration of $\mathrm{Cr}(\mathrm{III})$ the amount of its polynuclear hydroxocomplexes grows substantially (Figures 3 and 4). By comparison Figures 3 and 4 one can deduct that the complex $\mathrm{Cr}_{2}(\mathrm{OH})_{2}^{4+}$ for the $\mathrm{pH}$ range between 4 and 6 is formed. The larger $\mathrm{pH}$ area between 2 and 9 corresponding to the formation of polynuclear complexes $\mathrm{Cr}_{2}(\mathrm{OH})_{2}{ }^{4+}, \mathrm{Cr}_{3}(\mathrm{OH})_{4}^{5+}$ and $\mathrm{Cr}_{4}(\mathrm{OH})_{6}{ }^{6+}$ is found for $\mathrm{C}^{0}(\mathrm{Cr})=0.1 \mathrm{M}$. 


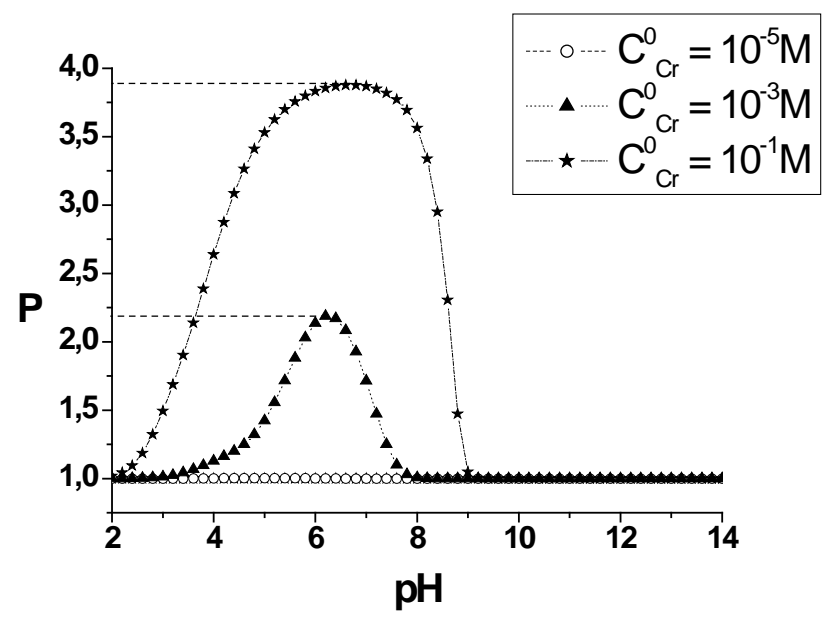

Figure 3. The degree of polynuclearity for hydroxocomplexes of $\mathrm{Cr}$ (III) versus pH at different analytical concentrations of $\mathrm{Cr}$ (III).

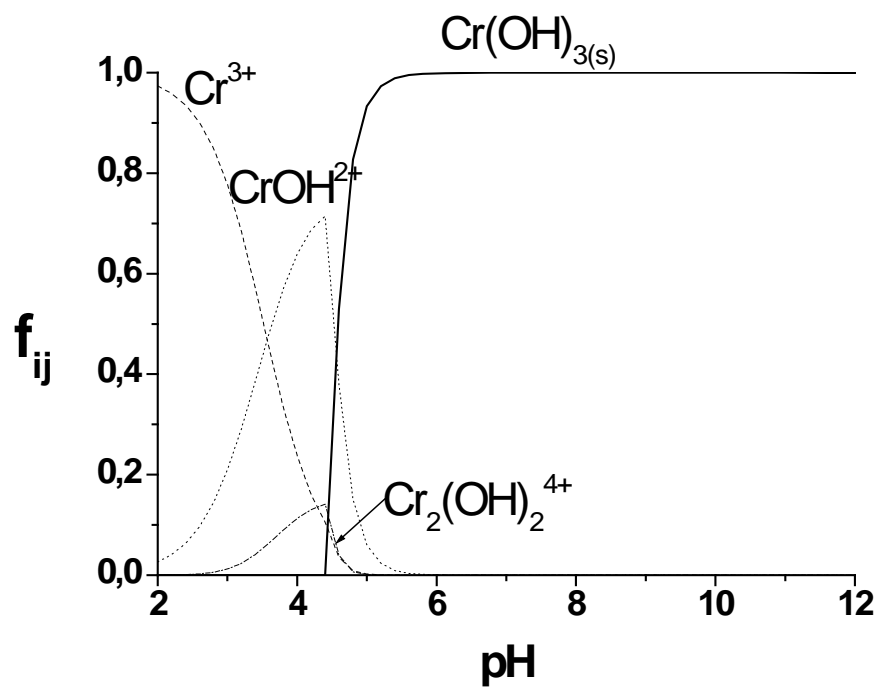

Figure 4. The curves of distribution of the $\mathrm{Cr}$ (III) hydroxocomplexes as a function of $\mathrm{pH}$ for $\mathrm{C}^{0}(\mathrm{Cr})=10^{-3} \mathrm{M}$.

On the Figure 5 the degree of polynuclear complex formation for $\mathrm{Cr}(\mathrm{VI})$ at its different analytical concentrations is represented. As one can see, the polynuclear $\mathrm{Cr}(\mathrm{VI})$ species are not formed at the concentration $\mathrm{C}^{0}(\mathrm{Cr}) \leq 10^{-5} \mathrm{M}$.

$\mathrm{Cr}(\mathrm{VI})$ may be present in the aqueous solution mainly in the form of chromate, dichromate, hydrogen chromate, chromic acid and hydrogen dichromate. The last two species were found only in the strongly acidic solutions. In typical surface waters, when the concentration of chromium is less than $5.0 \mu \mathrm{g} / \mathrm{L}$, only $\mathrm{HCrO}_{4}^{-}$and $\mathrm{CrO}_{4}^{2-}$ can be found. The soluble chromium species $\mathrm{CrO}_{4}{ }^{2-}$ and $\mathrm{Cr}(\mathrm{OH})_{3}$ are bio-accumulated as phyto- and zooplankton readily absorb chromium in all its forms. Nevertheless, the slow water flow and reducing bandwidth can cause adsorption of chromium on the surface of suspended particles in water and thus its deposition occurs.

Figure 6 shows DHCE of the chemical forms of $\mathrm{Cr}(\mathrm{VI})$ for its different total concentrations in aqueous solution. In contrast to $\mathrm{Cr}(\mathrm{III})$, DHCE for $\mathrm{Cr}(\mathrm{VI})$ are changed to a much lesser extent with the change in the total concentration of the metal ion in solution. 


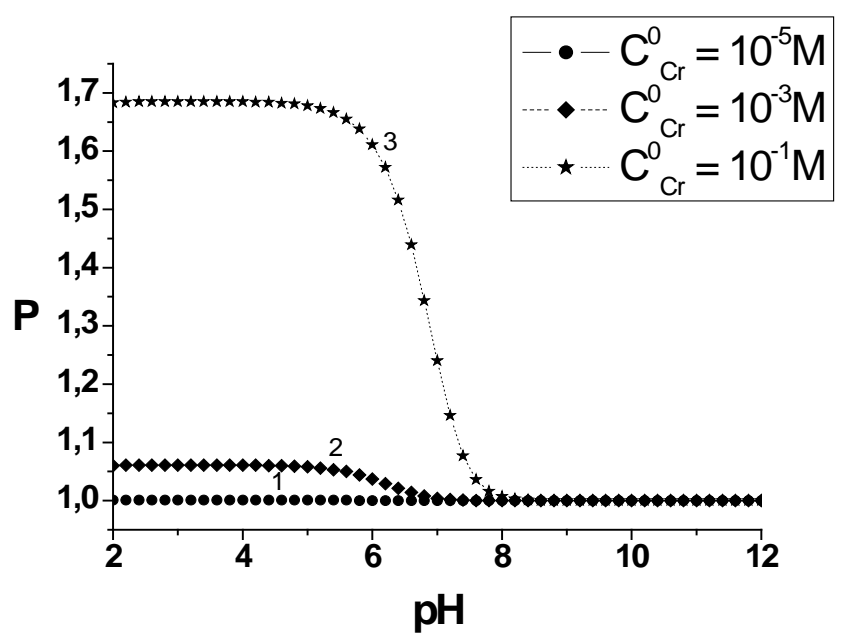

Figure 5. The degree of polynuclearity of the $\mathrm{Cr}$ (VI) species versus pH at different analytical concentrations of $\mathrm{Cr}(\mathrm{VI})$.

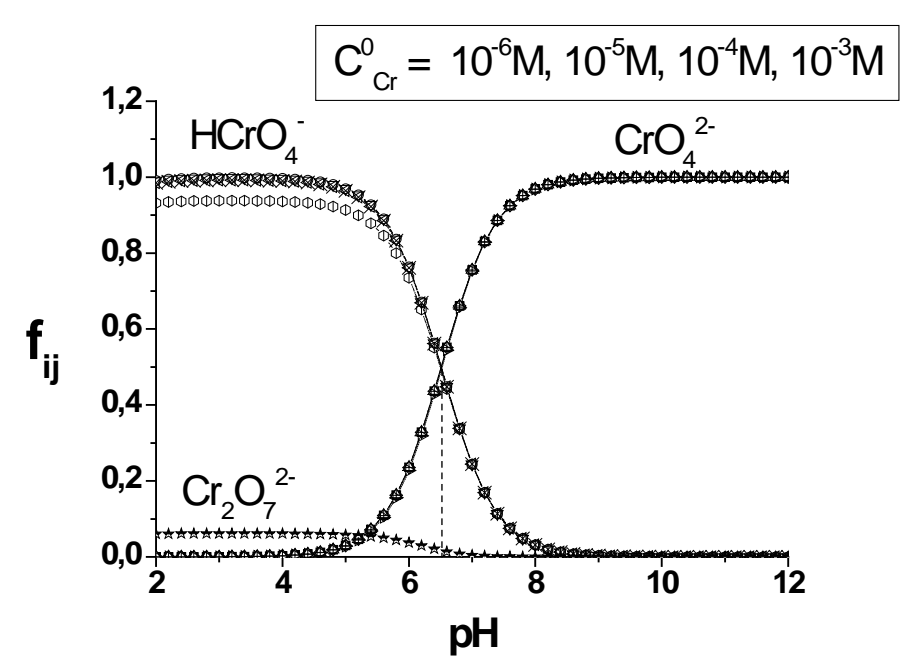

Figure 6. The curves of distribution of the complexes of $\mathrm{Cr}(\mathrm{VI})$ as a function of the pH solution at different analytical concentrations of $\mathrm{Cr}(\mathrm{VI})$.

\section{Conclusions}

It is worthy to note that our results, based on the thermodynamic analysis and graphic design of the calculated data in the form of the diagrams of heterogeneous chemical equilibria, are in good agreement with the available experimental data.

\section{Acknowledgement}

Author thanks to the Professor Igor Povar for his kind support, help and encouraging this research.

\section{References}

1. Guertin, J.; Jacobs, J.A.; Avakian, C.P. Chromium (VI) Handbook. CRC Press: Boca Raton, USA, 2004,800 p.

2. Kohl, W. Handbook of Materials and Techniques for Vacuum Devices. Reinhold Publishing: New York, 1967, $161 \mathrm{p}$.

3. Grevatt, P.C. Toxicological review of trivalent chromium. U.S. Environmental Protection Agency: Washington, 1998, $44 \mathrm{p}$

4. Vincent, J.B. The Nutritional Biochemistry of Chromium (III). Elsevier: Amsterdam, 2011, 292 p.

5. Zhitkovich, A. Chromium in Drinking Water: Sources, Metabolism, and Cancer Risks. Chemical Research in Toxicology, 2011, 24(10), pp. 1617-1629. 
6. Beaublen, S.; Nriagu, J.; Blowes, D.; Lawson, G. Chromium speciation and distribution in the great lakes. Environmental Science \& Technology, 1994, 28, pp. 730-736.

7. Richard, F.C.; Bourg, A.C.M. Aqueous geochemistry of chromium: a review. Water Research, 1991, 25, pp. 807-816.

8. Nriagu, J. Production and uses of chromium. Chromium in Natural and Human Environments. Wiley Interscience: New York, 1988, pp. 81-104.

9. Andreev, N.; Zubcov, E. The content of heavy metals $(\mathrm{Cd}, \mathrm{Cu}, \mathrm{Cr}$ and $\mathrm{Pb}$ ) in terrestrial snail body (helix, gastropoda, pulmonata) and health standards for food. Collection of Scientific Articles: Tighina, Eco-Tiras, 2006, pp. 43-46 (in Romanian).

10. Povar, I.; Rusu, V. Aluminium heterogeneous speciation in natural waters. Canadian Journal of Chemistry, 2012, 90, pp. 326- 332.

11. Fishtik, I.; Povar, I.; Vataman, I. Thermodynamics of Complex Equilibria in Salt Deposit-Aqueous Solution Systems. Estimation of Polynuclear Particle Formation. Journal of General Chemistry, 1987, 57, pp. 736-742 (in Russian).

12. Povar, I. Thermodynamic calculation of $\mathrm{pH}$ of the minimum solubility of slightly soluble oxides and hydroxides under metal ion polynuclear hydrolysis conditions. Ukrainian Chemistry Journal, 1994, 60, pp. 371-376 (in Russian).

13. Povar, I. Potentiometric determination of solubility products of poorly soluble hydroxides and acids. Journal of Analytical Chemistry, 1998, 53, pp. 1113 -1119 (in Russian).

14. Povar, I. Buffer properties of heterogeneous systems containing sparingly soluble acids and metal hydroxides. Russian Journal of Inorganic Chemistry, 1996, 41, pp. 1167-1172.

15. Povar, I. Buffer properties of heterogeneous water-salt systems in relation to the components of a low-solubility precipitate. Russian Journal of Inorganic Chemistry, 2000, 45, pp. 1632-1636.

16. Kragten, Y. Atlas of metal-ligand equilibria in aqueous solutions. Halsted Press: New York, 1978, 781 p.

17. Rai, D.; Sass, B. M.; Moore, D.A. Cr(III) hydrolysis constants and solubility of Cr(III) hydroxide. Inorganic Chemistry, 1987, 26, pp. 345-349.

18. Fishtik, I. et al. On the polynuclearity degree in solution complexation reactions. Russian Journal of Inorganic Chemistry, 1987, 32(8), pp. 2061-2064 (in Russian).

19. Ball, J. W.; Nordstrom. D. K. Critical Evaluation and Selection of Standard State Thermodynamic Properties for Chromium Metal and Its Aqueous Ions, Hydrolysis Species, Oxides, and Hydroxides. Journal of Chemical and Engineering Data, 1998, 43, pp. 895-918.

20. Stunzi, H. et al. Early stages of the hydrolysis of $\mathrm{Cr}(\mathrm{III})$ in aqueous solution. 4. Stability constants of the hydrolytic dimer, trimer and tetramer at $25^{\circ} \mathrm{C}$ and $\mathrm{I}=1 \mathrm{M}$. Inorganic Chemistry, 1989, 28, pp. 66-71. 